University of Tennessee College of Law

Legal Scholarship Repository: A Service of the Joel A. Katz Law Library

UTK Law Faculty Publications

2012

Triaging Appointed-Counsel Funding and Pro Se Access to Justice

Benjamin H. Barton

Follow this and additional works at: https://ir.law.utk.edu/utklaw_facpubs

Part of the Law Commons 


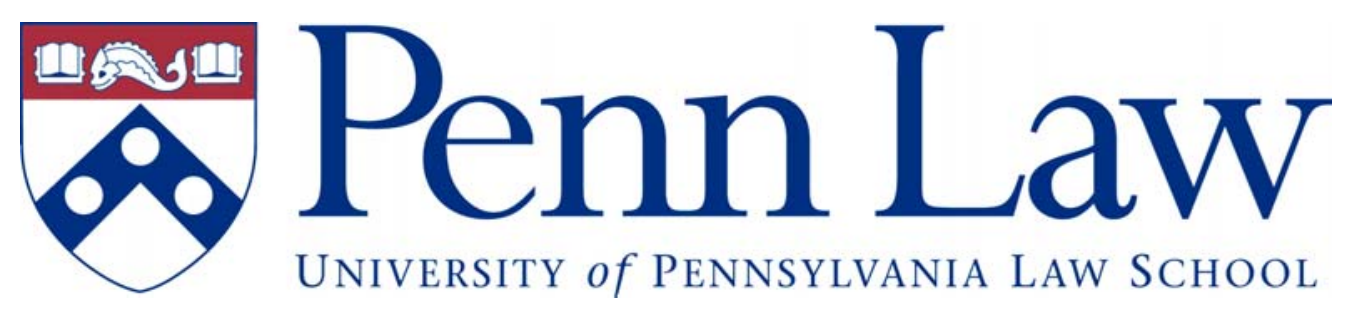

Public Law and Legal Theory Research Paper Series Research Paper No. \#11-36

\title{
Triaging Appointed-Counsel Funding and Pro Se Access to Justice
}

\author{
Benjamin H. Barton
}

University of Tennessee

Stephanos Bibas

University of Pennsylvania

This paper can be downloaded without charge from the Social Science Research Network Electronic Paper collection: http://ssrn.com/abstract=1919534 


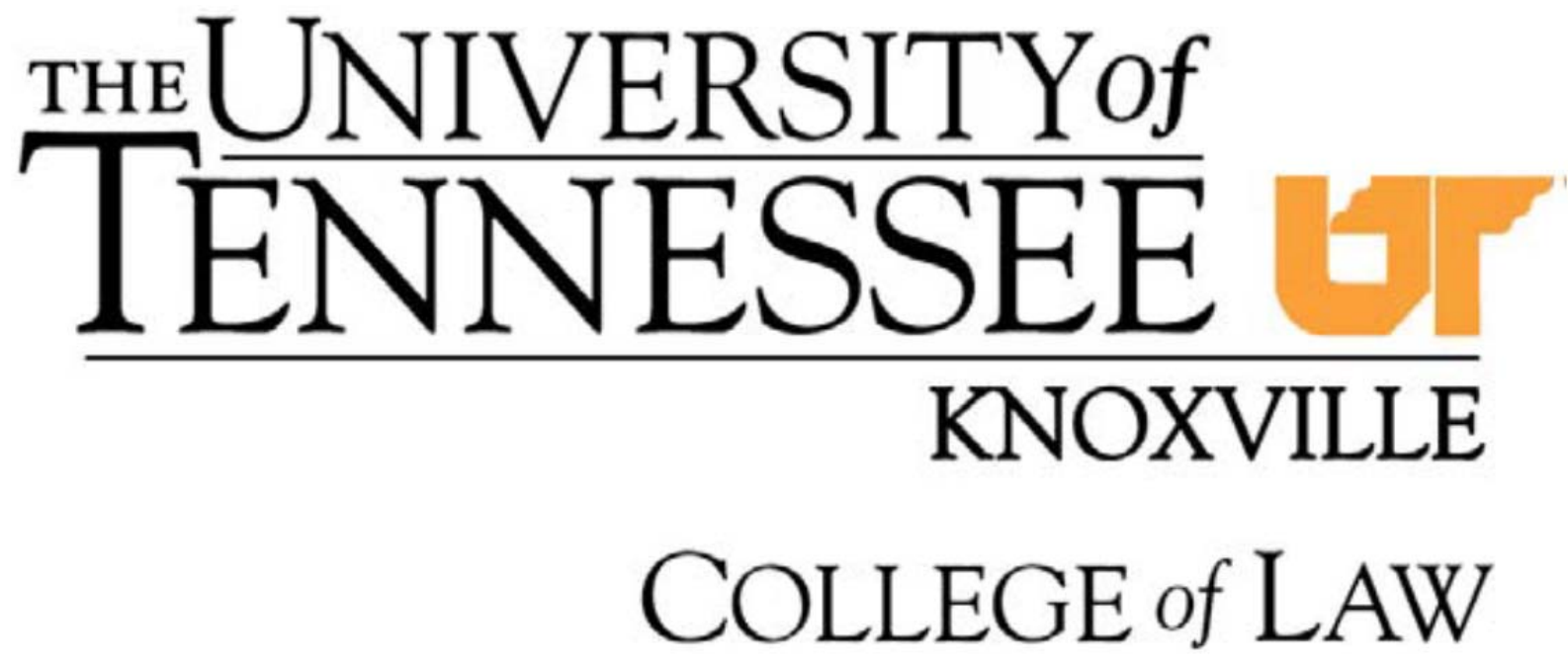

Legal Studies Research Paper Series

Research Paper \#157

September 2011

\title{
Triaging Appointed-Counsel Funding and Pro Se Access to Justice
}

\author{
Benjamin H. Barton
}

\&

Stephanos Bibas 


\title{
ARTICLE
}

\section{TRIAGING APPOINTED-COUNSEL FUNDING AND PRO SE ACCESS TO JUSTICE}

\author{
BENJAMIN H. BARTON \& STEPHANOS BIBAS ${ }^{\dagger}$
}

INTRODUCTION 968

I. TOO MANY NeEDS, TOO FEW DOLLARS. 972

A. Underfunding Criminal Counsel: Subverting Gideon

1. Capital Cases 972

2. Other Felonies 974

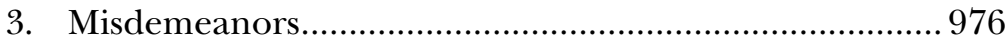

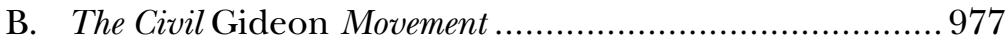

C. Unacknowledged Tradeoffs and Competing Demands .................. 980

II. TURNER'S TURN TO REALITY ..................................................... 982

A. Gradations of Complexity and Need............................................. 982

B. Concerns with Formality and Delay......................................... 983

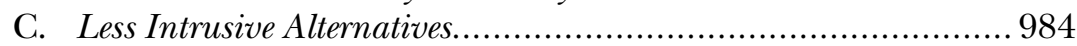

III. TWO-AND-A-HALF CHEERS FOR TURNER..................................... 985

A. The Wisdom of Not Recognizing a Procrustean Right .................. 985

B. More Sustainable Pro Se Court Reform ...................................... 987

C. The Implicit Role of Resource Constraints ................................... 990

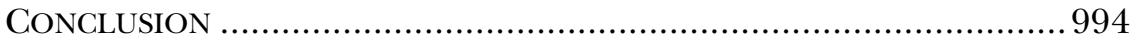

${ }^{\dagger}$ Benjamin Barton is the Director of Clinical Programs and Professor of Law at the University of Tennessee College of Law. Stephanos Bibas is a Professor of Law and Criminology and Director of the Supreme Court Clinic at the University of Pennsylvania Law School. Professor Bibas served as counsel of record for respondents, and Professor Barton filed an amicus curiae brief in support of respondents on the merits, in Turner v. Rogers, 131 S. Ct. 2507 (2011). Thanks to Darryl Brown and Erica Hashimoto for their comments on an earlier draft. 


\section{INTRODUCTION}

If appointing some lawyers is good, then appointing more lawyers must be better. At least that seems to be the logic of the civil Gideon movement, which favors appointing counsel in civil cases just as Gideon $v$. Wainwright required appointing counsel in criminal cases. The impulse is understandable: both indigent and pro se litigants face many hurdles in civil courts, and the stakes can be quite high. ${ }^{1}$ But even though criminal defendants do enjoy the Gideon right to counsel, the quality and availability of indigent criminal defense remain hobbled by inadequate funding. Gideon's shortcomings in the criminal context should caution us against assuming that a new judicially created right will alleviate chronic shortages.

Over the last century, Powell v. Alabama, Gideon, and related cases have steadily expanded the Sixth Amendment right to counsel in criminal prosecutions, from a right to retain one's own counsel to a right to appointed counsel in any case resulting in actual imprisonment. ${ }^{2}$ Counsel must also meet minimum standards of effectiveness. ${ }^{3}$ The services that must be provided have also grown to include expert assistance such as psychiatric examinations in criminal cases raising mental health issues. ${ }^{4}$ Civil litigants have had much less success, as the Supreme Court has repeatedly rejected a constitutional right to counsel in a variety of civil proceedings. ${ }^{5}$ Rather than giving up hope, however,

${ }^{1}$ See, e.g., Legal SERvs. CORP., DOCUMENTING THE JUSTICE GAP IN AMERICA 18-19 (2005) (identifying "a very serious shortage of civil legal assistance" and noting that fewer than one in five indigent defendants has access to civil legal assistance).

${ }^{2}$ See Powell v. Alabama, 287 U.S. 45, 71 (1932) (holding that appointment of counsel is necessary in a capital case "where the defendant is . . . incapable adequately of making his own defense because of ignorance, feeble mindedness, illiteracy, or the like"); Gideon v. Wainwright, 372 U.S. 335, 341-45 (1963) (extending Powell to noncapital prosecutions); Argersinger v. Hamlin, 407 U.S. 25, 37-38 (1972) (extending Gideon to any offense that results in imprisonment). But see Scott v. Illinois, 440 U.S. 367, 37374 (1979) (establishing an actual-imprisonment limitation on right to counsel).

${ }^{3}$ See Strickland v. Washington, 466 U.S. 668, 687 (1984) (setting the standard for ineffective assistance of counsel as "deficient" performance that actually prejudices the defendant).

${ }^{4}$ See Ake v. Oklahoma, 470 U.S. 68, 83 (1985).

${ }^{5}$ See, e.g., Lassiter v. Dep't of Soc. Servs., 452 U.S. 18, 31-33 (1981) (rejecting an automatic right to counsel in proceedings to terminate parental rights); Vitek v. Jones, 445 U.S. 480, 497 (1980) (Powell, J., concurring in part) (deciding that qualified assistance, but not an attorney, must be provided when a prisoner faces involuntary transfer to a mental hospital); Parham v. J.R., 442 U.S. 584, 606-07, 610 n.18 (1979) (holding that an impartial assessment, but not an adversarial hearing with a lawyer, is required before committing a minor to a mental hospital); Goss v. Lopez, 419 U.S. 565, 583 
scholars and activists have continued to advocate for broad civil Gideon rights. ${ }^{6}$ Most notably, the American Bar Association (ABA) endorses appointing counsel for all poor people in adversarial proceedings implicating basic human needs, such as food, shelter, safety, health, or child custody. ${ }^{7}$ Historically, bar associations' support for expanding Gideon has proven quite influential. ${ }^{8}$

Last year, the Supreme Court reopened the civil right-to-counsel debate by agreeing to hear Turner $v$. Rogers, in which a pro se mother sued a pro se father for failing to pay child support. ${ }^{9}$ The issue was whether the father had an automatic right to appointed counsel before he could be conditionally confined for civil contempt. ${ }^{10}$ Many activists hoped that the Court would overturn or narrow its earlier precedents and recognize a categorical right to counsel, at least in civil

(1975) (finding that students have no constitutional right to retain counsel in school disciplinary proceedings); Wolff v. McDonnell, 418 U.S. 539, 569-70 (1974) (declining to require retained or appointed counsel in prison disciplinary proceedings); see also Walters v. Nat'l Ass'n of Radiation Survivors, 473 U.S. 305, 320-26 (1985) (upholding a fee limitation on attorney compensation for veterans' benefits proceedings).

${ }^{6}$ For example, since 2006 there have been at least three civil Gideon law review symposium issues. See Symposium, An Obvious Truth: Creating an Action Blueprint for a Civil Right to Counsel in New York State, 25 TOuro L. REv. 1 (2009); Symposium, A Right to Counsel in Civil Cases: Civil Gideon in Maryland $\mathcal{E}$ Beyond, 37 U. BALT. L. REv. 1 (2007-2008); Edward V. Sparer Symposium: Civil Gideon: Creating a Constitutional Right to Counsel in the Civil Context, 15 TEMP. POL. \& CIV. RTS. L. REV. 501 (2006); see also CLEARINGHOUSE REV., July-Aug. 2006 (dedicating an entire issue to civil Gideon laws); Robert W. Sweet, Civil Gideon and Confidence in a Just Society, 17 YALE L. \& POL'y REV. 503, 50506 (1998) (arguing for an expanded due process right to representation).

${ }^{7}$ See Standing CommitTeE on Legal Aid \& INDigENT DefENDANTS ET AL., AM. BAR Ass'N, Report to THE House OF Delegates, Resolution 105 (REVISED) 1 (2010), available at http://www.americanbar.org/content/dam/aba/administrative/legal_aid_ indigent_defendants/ls_sclaid_105_revised_final_aug_2010.pdf. State bar associations have also chimed in. See, e.g., Thomas M. Burke, A Civil Gideon? Let the Debate Begin, 65 J. Mo. B. 5, 5 (2009) (advocating appointing counsel in civil proceedings where "basic human needs are at stake”); Diane S. Diel, Speaking for the Justice System, WIS. LAW., Dec. 2008, at 5, 5 (describing an inquiry by bar association presidents to then-PresidentElect Barack Obama as to his intentions to establish a federal civil Gideon); Scott Russell, Minnesota's Legal Safety Net: Many Hands Intertwined, 66 BENCH \& B. MinN., Mar. 2009, at 22, 25 (2009) (discussing civil Gideon as the latest advocacy response to the shortage of resources for indigent litigants); State Bar Signs on to Letter to Obama, McCain, MONT. LAW., Nov. 2008, at 11, 11 (encouraging presidential candidates to embrace an expanded right to counsel).

${ }^{8}$ For example, the Supreme Court included a long, supportive quotation from the ABA in extending Gideon to misdemeanor cases in Argersinger v. Hamlin, 407 U.S. 25, 39 (1972).

\footnotetext{
${ }^{9} 131$ S. Ct. 2507, 2512 (2011).

${ }^{10} \mathrm{Id}$.
} 
cases that result in a deprivation of liberty. ${ }^{11}$ Instead, all nine Justices rejected the claimed right to counsel, though a five-Justice majority required courts to help pro se litigants navigate the process themselves. $^{12}$ In child support proceedings, the majority noted, courts may provide this assistance by (1) giving notice that ability to pay is a key issue; (2) asking defendants to fill out financial disclosure forms; (3) allowing defendants to respond to questions about their finances; and (4) making express findings regarding defendants' ability to pay. ${ }^{13}$

Turner dealt the death blow to hopes for a federally imposed civil Gideon. Thirty years ago, the Lassiter court rejected a civil Gideon right in termination-of-parental-rights cases by a 5-4 vote over a vehement dissent. ${ }^{14}$ By 2011, the civil Gideon argument could not garner a single vote. That was true even though the defendant in Turner faced one year in jail and Lassiter in dictum had presumed a right to appointed counsel when physical liberty is at stake. ${ }^{15}$ Given the importance of the liberty interest in Turner, the Court's decision leaves little room for advocates to insist that a lesser liberty interest qualifies for Gideon's protections.

Though Turner upset many civil Gideon proponents, ${ }^{16}$ we should not lament the decision but instead (mostly) praise it. In rejecting a broad new constitutional right, the Court steered toward more sustainable reform for pro se litigants. The Court's solution is far more realistic than a grandiose new right to counsel. Indeed, funding for counsel is scarce, existing lawyers are already overtaxed, and appointing civil lawyers would siphon time and resources from felony cases, which are typically more important and more complex. In a world of scarce resources, legislatures, courts, and legal aid organizations need flexibility in order to triage cases. Both the Constitution and sensible policy thus favor reserving appointed counsel primarily for criminal

${ }^{11}$ For a partial list of the amicus briefs filed in Turner $v$. Rogers in support of a civil Gideon right, see infra note 76.

12 Turner, 131 S. Ct. at 2512.

13 Id. at 2519.

${ }^{14}$ See Lassiter v. Dep't of Soc. Servs., 452 U.S. 18, 35 (1981) (Blackmun, J., dissenting) ("[T]he Court avoids what seems to me the obvious conclusion that due process requires the presence of counsel for a parent threatened with judicial termination of parental rights, and, instead, revives an ad hoc approach thoroughly discredited nearly 20 years ago in Gideon v. Wainwright.").

${ }^{15}$ Id. at 26-27, quoted in Turner, 131 S. Ct. at 2516.

${ }^{16}$ For example, the legal blog Concurring Opinions hosted a post-Turner symposium that largely condemned the civil Gideon portion of the case. See Archive for the Turner Symposium, CONCURRING OPINIONS, http://www.concurringopinions.com/ archives/category/symposium-turner-v-rogers (last visited Jan. 15, 2012). 
cases. Appointment of counsel in civil cases must be selective and discretionary, used only for the most complex and most meritorious cases. While giving everyone a lawyer is an impossible dream, less expensive pro se court reform is far more feasible. Turner did not explicitly discuss the importance of resource constraints, but its holding makes much more sense given the reality of limited funds.

Properly handled, pro se court processes can be cheaper and fairer. Extraordinarily, the Court noted that appointing counsel in pro se civil cases could make the proceedings "less fair overall" and introduce unwarranted "formality or delay." Though that observation is a matter of common sense, the Court's prior case law had consistently praised lawyers' role in guaranteeing just procedures. ${ }^{18}$ Turner's changed tune reflects a more mature, more nuanced view of lawyers and the complexity inherent in the adversarial system. If Turner helps to spur new pro se court processes that are simpler and fairer, everyone will benefit.

Part I of this Article surveys the state of the scholarly literature and case law before Turner. Academics had long complained about chronic underfunding of indigent criminal defense while calling for more money across the board. Civil Gideon reformers had likewise called for funding civil counsel programs. But there was little sense that these goals entailed tradeoffs and little emphasis on pro se court reform as a viable, less costly alternative. The same activists sometimes endorsed both of these goals, which are at least in tension with each other, if not outright contradictory.

Part II analyzes Turner. The Court recognized that not all cases are alike: even where the stakes are high, some cases are not complex enough to require a lawyer. It also worried that appointing counsel would add formality and delay, harming innocent parties on the other side of civil proceedings. Further, the Court introduced a new focus on the availability of less intrusive alternatives, notably pro se assistance.

Part III gives two-and-a-half cheers for Turner's shift. The Court wisely avoided creating a Procrustean civil Gideon rule and carefully separated civil from criminal cases. It steered future developments toward more sustainable pro se court reform. And though the Court

${ }^{17} 131$ S. Ct. at 2519.

${ }^{18}$ Starting with Powell v. Alabama and continuing through to Gideon and Argersinger, the Supreme Court has treated the availability of a lawyer as an unqualified good and a necessary ingredient of fair judicial procedures. For a discussion of some of this case law, see BENJAMIN H. BARTON, THE LAWYER-JUdGE BIAS IN THE AMERICAN LEGAL SYSTEM 54-60 (2011). 
did not discuss funding limitations, its approach is consistent with the need to triage cases. Criminal cases are more important and more complex, and there is less of a role for lawyers in many civil cases.

We cannot and will not provide lawyers to everyone. Turner rightly rejected that impossible dream. It is far more important to fund appointed lawyers in serious felony cases than it is to provide them in, say, housing court. This Article concludes that the task ahead is to make civil lawsuits simpler and more accessible to nonlawyers.

\section{ToO MANy NeEds, TOO FeW DOLLARS}

In the decades preceding Turner, scholars and advocates challenged the dearth of appointed counsel and resources on a variety of fronts. Capital defendants, they noted, suffer from woefully inadequate funding for lawyers and support services. Other felony and misdemeanor defendants likewise have overworked, underfunded lawyers who quickly press them to plead guilty. The result is an epidemic of ineffective assistance of counsel. In civil cases, resources are still scarcer. There are few appointed lawyers even in cases with significant stakes, such as divorce, child custody, child support, housing, and immigration proceedings.

Yet these advocates rarely acknowledged the tension between their competing goals in the criminal and civil contexts. Funding to appoint counsel is limited, and guaranteeing lawyers in more cases will spread existing resources too thin. As it is, criminal defense lawyers risk being ineffective because they have too little time and too few support services. A broad civil Gideon right would thus effectively undercut Gideon itself.

\section{A. Underfunding Criminal Counsel: Subverting Gideon}

\section{Capital Cases}

For almost eighty years, the Supreme Court has recognized a right to appointed counsel in capital cases. ${ }^{19}$ Yet, to this day, indigent capital defense remains scandalously underfunded. To guarantee effective counsel, states must offer enough money to attract and retain qualified, experienced lawyers and to give them the investigative, forensic, and administrative support they need. But funding indigent defense, especially capital defense, is hardly a political priority, so attorney

${ }^{19}$ See Powell v. Alabama, 287 U.S. 45, 73 (1932). 
compensation is paltry. Capital defenders may be paid flat fees or hourly rates subject to low statutory caps, which may work out to twelve dollars per hour or less. ${ }^{20}$

Nor is there enough funding for support services. Effective capital defense requires thorough research into the facts surrounding the crime as well as the defendant's background, family, upbringing, mental health, and character. This research necessitates private investigators, paralegals, secretaries, and quite possibly forensic experts, psychiatrists, doctors, and social workers. But the compensation described above hardly covers the basic overhead costs for secretaries or paralegals. And many capital defenders must perform their jobs without any investigative or expert assistance at all. Courts sometimes deny funding by requiring strong showings to justify expenses, or they award only several hundred dollars to cover an entire trial. ${ }^{21}$ Poor funding thus undercuts the right to expert assistance. ${ }^{22}$ As a result, few experienced lawyers are willing to take capital cases, and those who do lack the time and tools to do a thorough job.

The problem is especially acute because capital cases are among the longest and most complex proceedings in our legal system, and capital defendants have the most at stake. Moreover, capital defense attorneys are often outgunned by prosecutors who enjoy better pay and investigative and expert support as well as more experience and specialization in capital punishment. ${ }^{23}$ In some states, certain prosecu-

${ }^{20}$ See, e.g., Martinez-Macias v. Collins, 979 F.2d 1067, 1067-68 (5th Cir. 1992) (overturning death sentence on federal habeas petition based on ineffective assistance of counsel where counsel was paid $\$ 11.84$ per hour and "the justice system got only what it paid for"); Stephen B. Bright, Counsel for the Poor: The Death Sentence Not for the Worst Crime but for the Worst Lawyer, 103 YALE L.J. 1835, 1838, 1853, 1868 (1993) (collecting examples of inadequate compensation for indigent defense, with some rates as low as \$4.05 per hour); Adam M. Gershowitz, Statewide Capital Punishment: The Case for Eliminating Counties' Role in the Death Penalty, 63 VAND. L. REV. 307, 323-26 (2010) (describing egregious examples of inadequate, incompetent, and underpaid indigent defense).

${ }^{21}$ See Paul C. Giannelli, Daubert and Forensic Science: The Pitfalls of Law Enforcement Control of Scientific Research, 2011 U. ILL. L. REV. 53, 76-77 \& n.158 (noting underfunding of expert assistance for indigent defendants and arguing that "the asymmetry in resources is pronounced").

${ }^{22}$ See Cara H. Drinan, The Revitalization of Ake: A Capital Defendant's Right to Expert Assistance, 60 OKLA. L. REV. 283, 288-96 (2007) (describing a variety of statutory and judicial hurdles that contribute to a pervasive lack of expert assistance in capital cases).

${ }^{23}$ See Bright, supra note 20, at 1844-48 ("In contrast to the prosecution's virtually unlimited access to experts and investigative assistance, the lawyer defending the indigent accused in a capital case may not have any investigative or expert assistance to prepare for trial and present a defense."). 
tors specialize in capital prosecutions, while there is no comparable public defender unit. Instead, defense lawyers are appointed ad hoc and cannot develop repeat-player expertise. ${ }^{24}$

Two recent Georgia cases are particularly galling. In Phan v. State and Weis v. State, the Georgia Supreme Court forced death penalty trials to proceed even though Georgia had stopped paying the defendants' lawyers when the State's indigent defense fund went bankrupt. ${ }^{25}$

The result is a playing field tilted toward death. Ineffective assistance of counsel, despite the guarantee in the Sixth Amendment, is rampant. The American Bar Association has lamented that "grossly unqualified and under compensated lawyers who have nothing like the support necessary to mount an adequate defense are often appointed to represent capital clients. In case after case, decisions about who will die and who will live turn ... on the nature of the legal representation the defendant receives." ${ }^{26}$ Poor training, preparation, and compensation infect many capital trials. ${ }^{27}$ Significant funding increases are needed to train and retain competent capital defense lawyers and to give them the tools to do their job effectively.

\section{Other Felonies}

The capital defense system has received much attention-and some additional funding-over the past twenty years. ${ }^{28}$ The rampant underfunding of noncapital defense, however, has largely flown under the radar. Felony defenders are frequently paid much less than the prosecutors they oppose. $^{29}$ Compensation can run as low as $\$ 40$ per hour,

${ }^{24}$ See Stephen B. Bright, Legal Representation for the Poor: Can Society Afford This Much Injustice?, 75 MO. L. REV. 683, 690 (2010) (explaining the ad hoc system of judicially appointing capital defense attorneys and the resulting perverse incentives for lawyers who depend on judges for their income).

${ }^{25}$ Phan v. State, 699 S.E.2d 9, 10-11 (Ga. 2010); Weis v. State, 694 S.E.2d 350, 35358 (Ga. 2010). For a gripping overview of the logical and legal gymnastics in these opinions, see Bright, supra note 24, at 691-97.

${ }^{26}$ LeSLIE A. HARRIS, AM. BAR ASS'N, REPORT TO THE HOUSE OF DELEGATES 4 (1997), available at http://www.americanbar.org/content/dam/aba/migrated/legalservices/ downloads/sclaid/20110325_aba_107.authcheckdam.pdf.

${ }^{27}$ See Ruth E. Friedman \& Bryan A. Stevenson, Solving Alabama's Capital Defense Problems: It's a Dollars and Sense Thing, 44 ALA. L. REV. 1, 26-32 (1992) (describing these pervasive inadequacies in Alabama).

${ }^{28}$ For example, the Justice for All Act of 2004 offers federal funding to improve state capital defense. Justice for All Act of $2004 \S \S 421-422$, 42 U.S.C. $\S \S 14163-14163 a$ (2006).

${ }^{29}$ See Ronald F. Wright, Parity of Resources for Defense Counsel and the Reach of Public Choice Theory, 90 IOWA L. REV. 219, 230 (2004) ("By and large, entry-level prosecutors 
and per-case caps can be as low as $\$ 600$ per case for less serious felonies and $\$ 1235$ per case for more serious felonies. ${ }^{30}$ Further, indigent defense lawyers carry heavy caseloads, often juggling hundreds of cases at once. $^{31}$ As one judge described managing 418 defendants over seven months in New Orleans, "Not even a lawyer with an S on his chest could effectively handle this docket." ${ }^{, 2}$ Defenders, unlike prosecutors, typically have little or no investigative or expert support. ${ }^{33}$ A survey of nearly two thousand felony cases in Alabama showed that "no motions were filed for funds for experts or investigators in $99.4 \%$ of the cases." ${ }^{34}$

Felony defenders also have little time to meet with their clients, particularly when a face-to-face meeting would require a long trip to a distant jail. Their only communication with each client may be no more than a hurried conversation in a courtroom hallway or holding cell in the few minutes before a court appearance. To manage their crushing workloads, defense lawyers very often "meet 'em and plead "em," pressing their clients to plead guilty immediately before doing any investigation..$^{35}$ Naturally, defendants mistrust lawyers whose only interest appears to be getting rid of their case. ${ }^{36}$

Because funds are tight, many counties contract these services out to the lowest bidder for a flat fee. ${ }^{37}$ Lawyers who accept these contracts can continue to earn more money by handling private cases, and there is no financial incentive to attract good lawyers or provide zealous representation. Instead, the system encourages lawyers

earn higher salaries than entry-level public defenders. The salary differences persist at every level of experience ....").

${ }^{30}$ Darryl K. Brown, Epiphenomenal Indigent Defense, 75 MO. L. REV. 907, 912-13 (2010); see also STANDing COMM. ON LEGAL AID \& INDigent DEFENDANTS, AM. BAR ASS'N, GIDEON's BROKEN PROMISE: AMERICA's CONTINUING QUEST FOR EQUAL JUSTICE 9-10 (2004) [hereinafter GIDEON'S BROKEN PROMISE] (cataloguing reported instances of inadequate attorney compensation in various jurisdictions).

${ }^{31}$ See Bright, supra note 20, at 1850-51; Wright, supra note 29, at 231.

${ }^{32}$ State v. Peart, 621 So. 2d 780, 789 (La. 1993) (quoting trial judge).

${ }^{33}$ Wright, supra note 29, at 231.

${ }^{34}$ GIDEON'S BROKEN PROMISE, supra note 30, at 19.

${ }^{35}$ See id. at 16 (describing the typical practice in Calcasieu Parish, Louisiana, as related by several witnesses who experienced the parish's "meet 'em and plead 'em" lawyers).

${ }^{36}$ See Alexandra Natapoff, Speechless: The Silencing of Criminal Defendants, 80 N.Y.U. L. REv. 1449, 1462-63 (2005) (noting the mistrust of public defenders and explaining that it exacerbates this "not uncommon ... 'meet 'em and plead 'em' scenario").

${ }^{37}$ See Nat'l Ass'n of Criminal Def. LaWyers, Low-Bid Criminal Defense CONTRACTING: JUSTICE IN RETREAT 1 (1997). 
to scrimp on support services, as any overhead or expert costs come directly out of their own pay.

Numerous public interest organizations decry this state of affairs and rightly call for reform. As the American Bar Association put it, "Forty years after Gideon v. Wainwright, indigent defense in the United States remains in a state of crisis" in part because "[f] unding for indigent defense services is shamefully inadequate." 39 The Constitution Project emphatically agrees, ${ }^{40}$ as does the National Association of Criminal Defense Lawyers. ${ }^{41}$

In short, underfunded indigent defense systems offer chronically ineffective representation. Defender organizations and public interest groups have tried to solve the problem by filing lawsuits challenging this state of affairs and seeking better funding. These lawsuits, however, have failed to result in meaningful change. ${ }^{42}$

\section{Misdemeanors}

In Argersinger $v$. Hamlin, the Supreme Court extended the Sixth Amendment right to counsel to misdemeanor charges that can result in actual imprisonment. ${ }^{43}$ Thus, the right extends not only to hundreds of thousands of felony cases per year, but also to millions of misdemeanors as well. ${ }^{44}$ Alabama $v$. Shelton further expanded that right

${ }^{38}$ See id. at 2 ("Fixed-price contracts, requiring representation of all cases, inevitably result in case overload and inadequate representation with built-in incentives to process cases quickly and disincentives to take cases all the way to trial. Such systems discourage the use of investigators, forensic specialists, [and] expert witnesses ....”).

39 GIDEON'S BROKEN PROMISE, supra note 30, at v.

${ }^{40}$ NAT'L Right to Counsel Comm., The Constitution Project, Justice Denied: AMERICA's CONTINUING NEGLECT OF OUR CONSTITUTIONAL Right TO COUNSEL 7 (2009) (noting that inadequate funding leads to "astonishingly large caseloads" and "second-rate legal services").

${ }^{41}$ See NAT'L ASS'N OF CRIMINAL DEF. LAWYERS, supra note 37, at 1 (complaining that "maximum caseload standards are routinely ignored, needed experts are underutilized and prolonged appellate delays are commonplace" (footnotes omitted)).

${ }^{42}$ See Note, Effectively Ineffective: The Failure of Courts to Address Underfunded Indigent Defense Systems, 118 HARV. L. REV. 1731, 1741 (2005) (noting that even three widely celebrated litigation success stories reflect "judicial reluctance to undertake sustainable systemic indigent defense reform”). But cf. Cara H. Drinan, The Third Generation of Indigent Defense Litigation, 33 N.Y.U. REV. L. \& SOC. CHANGE 427, 462-63 (2009) (acknowledging the mixed record of success of these suits but expressing optimism about future strategies focusing on indigent defense litigation in federal court).

${ }^{43} 407$ U.S. 25, 37-40 (1972).

${ }^{44}$ See Erica J. Hashimoto, The Price of Misdemeanor Representation, 49 WM. \& MARY L. REV. 461, 477 (2007) (reporting estimates that, since 1972, 690,000 felony cases and up to 2.7 million misdemeanor cases per year required appointed counsel). 
to cases resulting in probation that could eventually be enforced by imprisonment. ${ }^{45}$ Thus, a fair number of misdemeanor defendants receive appointed counsel; in federal court, for example, one-quarter did between 2000 and $2005 .^{46}$ Often, however, counsel is not immediately available and defendants must wait before receiving lawyers, sometimes for months, even if they are jailed pending trial. ${ }^{47}$

Even when lawyers are appointed, they often must juggle hundreds of misdemeanors and have little time to spend on each one. Particularly in the most minor cases, defense lawyers do little more than ask for, and often receive, lenient dispositions such as suspended sentences. ${ }^{48}$ Because of resource constraints, they hardly have the time or incentive to do anything else. Prosecutors and judges, for their part, discourage filing motions and routinely treat minor cases as eligible for nonprison sentences. ${ }^{49}$ Josh Bowers, a former Bronx public defender, has reported that prosecutors and defenders alike view some low-level cases, such as public-order cases, as "disposables" that merit cookie-cutter dispositions. ${ }^{50}$ This is a natural response to the crushing number of misdemeanor cases on top of felonies: every actor in the criminal justice system simply hurries cases along the plea-bargaining assembly line.

\section{B. The Civil Gideon Movement}

Many parties to important civil disputes cannot afford counsel. Tenants facing eviction, immigrants facing deportation, parents facing

${ }^{45} 535$ U.S. 654, 658, 674 (2002).

${ }^{46}$ Hashimoto, supra note 44, at 489-90.

${ }^{47}$ See Michael Pearson, Judge: Fulton Must Cut Jail Load, ATLANTA J.-CONST., Apr. 17, 2002, at 1B, available at 2002 WLNR 4649292 (reporting that "lengthy delays in processing suspects accused of minor crimes is one of the main reasons the county jail is overcrowded" and that "[s]ome [inmates] now go months before they are even arraigned" and receive lawyers). In Mississippi in 2003, a man charged with resisting arrest spent two-and-a-half months in the county jail before he saw a lawyer. Adam Liptak, County Says It's Too Poor to Defend the Poor, N.Y. TIMES, Apr. 15, 2003, at A1. The maximum punishment for resisting arrest in Mississippi is six months in jail and a fivehundred dollar fine. MISS. CODE ANN. §97-9-73 (West 2005).

${ }^{48}$ See Milton Heumann, Plea Bargaining: The Experiences of Prosecutors, JUDGES, AND DEFENSE ATTORNEYS 70, 72, 81 (1978).

${ }^{49}$ See id. at 61-66, 103-06.

${ }^{50}$ Josh Bowers, Legal Guilt, Normative Innocence, and the Equitable Decision Not to Prosecute, 110 COLUM. L. REV. 1655, 1709 (2010). This concern is not new. In Argersinger, the Court warned of the dangers of "assembly-line justice" and plea mills for misdemeanor defendants. See Argersinger v. Hamlin, 407 U.S. 25, 34-36 (1972). 
termination of parental rights, and employees facing loss of their jobs have no automatic right to appointed counsel. This is true even when their opponent (be it the state, a landlord, or an employer) is represented by counsel. The Legal Services Corporation (LSC) has estimated that less than one-fifth of low-income people's legal needs are being met. ${ }^{51}$ As a result, often legal services offices can offer only brief advice, placement on a long waiting list for help, or nothing at all. ${ }^{52}$ Even the current low level of LSC funding is in danger of being cut much further. ${ }^{53}$

To many, an appointed lawyer seems essential to balance the scales and protect the poor and powerless. That understanding seems to comport with Gideon itself, which recognized that "lawyers in criminal courts are necessities, not luxuries." ${ }^{\text {, }}$

Calls for a parallel Gideon right in civil cases followed almost immediately on the heels of Gideon. As early as 1965, an indigent litigant argued (unsuccessfully) that Gideon and the Due Process Clause required appointing counsel in a property dispute. ${ }^{55}$ Likewise, a 1967 Yale Law Journal Note argued that "if an affluent [civil] litigant cannot get a fair trial without a lawyer, an indigent litigant cannot either." Other commentators soon followed. ${ }^{57}$

${ }^{51}$ Legal Servs. CorP., Documenting the Justice GaP IN America 3 (updated ed. 2009), available at http://www.lsc.gov/sites/default/files/LSC/pdfs/documenting_ the_justice_gap_in_america_2009.pdf.

52 See Deborah L. RhODE, ACCESS TO JustiCE 13-14 (2004).

${ }^{53}$ The House Appropriations Committee proposed a \$104 million funding cut for the LSC for Fiscal Year 2012, a 26\% reduction in funding from 2011. See Press Release, Legal Servs. Corp., House Proposal Would Cut Civil Legal Aid by \$104 Million (July 6, 2011), available at http://www.lsc.gov/media/press-releases/house-proposal-would-cutcivil-legal-aid-104-million.

${ }^{54}$ Gideon v. Wainwright, 372 U.S. 335, 344 (1963).

${ }_{55}$ Sandoval v. Rattikin, 395 S.W.2d 889, 893-94 (Tex. Civ. App. 1965), cert. denied, 385 U.S. 901 (1966).

${ }^{56}$ Note, The Indigent's Right to Counsel in Civil Cases, 76 YALE L.J. 545, 549 (1967).

${ }^{57}$ See, e.g., Francis William O'Brien, Why Not Appointed Counsel in Civil Cases? The Swiss Approach, 28 OHIO ST. L.J. 1, 13 (1967) (querying why Americans' constitutional sensibilities "dull when innocent people are made to suffer by unjust decisions in civil cases"); Note, The Emerging Right of Legal Assistance for the Indigent in Civil Proceedings, 9 U. MICH. J.L. REFORM 554, 556 (1976) (arguing that "logic indicates that civil property rights should receive the same protection" as "life and liberty"); Note, The Indigent's Right to Counsel in Civil Cases, 43 FORDHAM L. REV. 989, 997 (1975) (suggesting one "instance where constitutional rights may be violated by the failure to appoint counsel in civil litigation"); Note, The Right to Counsel in Civil Litigation, 66 CoLUM. L. REV. 1322, 1331 (1966) ("[T] he inability of the unskilled litigant . . seems no less debilitating in most civil litigation.”). 
Gideon was followed by two Court cases that seemed to support a civil extension of Gideon. First, In re Gault extended Gideon to juvenile proceedings that might result in confinement, even though juvenile proceedings are not technically criminal. ${ }^{58}$ Gault reasoned that due process guaranteed appointed counsel because the juvenile's liberty was at stake; the Court did not rely upon the Sixth Amendment at all. ${ }^{59}$ Thus, where the liberty interest is important enough, the due process right to appointed counsel can extend beyond Sixth Amendment criminal cases.

Five years later, Argersinger v. Hamlin extended the Sixth Amendment right to appointed counsel beyond felonies to any misdemeanor prosecution that resulted in jail time, however short. ${ }^{60}$ That set a low bar for liberty interests, as many civil cases involve more serious deprivations than a day in jail: consider deportation, termination of parental rights, or a year in jail for civil contempt. Taken together, Gault and Argersinger seemed to support a civil Gideon right. Nevertheless, no lower court announced a broad constitutional guarantee of appointed counsel in a civil case between Gideon and Lassiter, and the Supreme Court cases between Argersinger and Lassiter were a mixed bag. ${ }^{61}$

Lassiter itself dealt a crippling blow to civil Gideon hopes. It addressed a particularly serious liberty interest-termination of parental rights. $^{62}$ The Court presumed that "there is a right to appointed counsel only where the indigent ... may lose his personal freedom." " In the absence of actual incarceration, this presumption weighs "against" appointment of counsel. ${ }^{64}$ Lassiter also addressed a case brought by a government lawyer in an area of law that can be quite complex. ${ }^{65} \mathrm{Nev}$ ertheless, the Court recognized no right to counsel.

${ }^{58}$ See 387 U.S. 1,41 (1967).

${ }^{59} I d$. at $36-42$.

${ }^{60} 407$ U.S. 25, 37 (1972).

${ }^{61}$ See, e.g., In re Smiley, 330 N.E.2d 53, 56-57 (N.Y. 1975) (holding that indigent wives in divorce proceedings have no right to publicly compensated counsel and that the issue is more appropriate for legislative resolution). For a helpful overview of the pre-Lassiter cases and the difficulty in squaring them, see Turner v. Rogers, 131 S. Ct. 2507, 2516-17 (2011).

${ }^{62}$ Lassiter v. Dep't of Soc. Servs., 452 U.S. 18, $20-21$ (1981).

${ }^{63} I d$. at 27.

${ }^{64} \mathrm{Id}$.

${ }^{65}$ See id. at 30 (" $[\mathrm{T}]$ he ultimate issues with which a termination hearing deals are not always simple...."). 
Following Lassiter, civil Gideon hopes lay fallow for many years. ${ }^{66}$ One sign of a rekindling of interest was U.S. District Judge Robert Sweet's 1997 speech at Yale Law School advocating for appointed counsel in civil matters. ${ }^{67}$ The speech was published in the Yale Law and Policy Review and may have helped to renew interest in civil Gideon rights. $^{68}$ Some of these new supporters advocate civil Gideon rights in a specific area of civil law; others attack Lassiter head-on; and still others read U.S. treaty obligations as requiring appointed civil counsel. ${ }^{69}$

\section{Unacknowledged Tradeoffs and Competing Demands}

Many proponents of a civil Gideon right fail to recognize three fundamental truths: First, though Gideon has improved the quality of felony defense somewhat, it has hardly been a ringing success, primarily because funds are inadequate and courts are loath to overturn convictions based on ineffective assistance of counsel. Second, a judicially created civil Gideon right would be even less protected than indigent criminal defense. Third, a civil Gideon right would likely undermine indigent criminal defense by stretching limited resources further. Even if the money did not come directly from criminal defense funding, other areas of state budgets would feel the strain. Supporters of recognizing a civil Gideon and of providing adequate funding for indigent criminal defense see themselves as fighting the same battle for justice, without acknowledging the inevitable tradeoffs between the two goals. $^{70}$

${ }^{66}$ See Howard H. DANA, Am. Bar Ass'N, Report to The House of Delegates, RESOLUTION 112A, at 10, available at http://www.americanbar.org/content/dam/ aba/administrative/legal_aid_indigent_defendants/ls_sclaid_06A112A.pdf ("For over two decades, the Lassiter decision appeared to paralyze serious consideration of a right to counsel in civil cases.").

${ }^{67}$ Sweet, supra note 6, at 505-06.

${ }^{68}$ A Westlaw search in the JLR database for the term "civil Gideon" finds 217 articles, with only three mentions predating the publication of Sweet's speech.

${ }^{69}$ See, e.g., Laura K. Abel, A Right to Counsel in Civil Cases: Lessons from Gideon v. Wainwright, 15 TEMP. POL. \& CIV. RTS. L. REV. 527, 531-34 (2006) (asserting that Lassiter, like Betts $v$. Brady before it, should be overturned); Russell Engler, Shaping a ContextBased Civil Gideon from the Dynamics of Social Change, 15 TEMP. POL. \& CIV. RTS. L. REV. 697, 712 (2006) (arguing that certain private custody cases "are strong starting points for civil Gideon strategies”); Sarah Paoletti, Deriving Support from International Law for the Right to Counsel in Civil Cases, 15 TEMP. PoL. \& CIV. RTS. L. REV. 651, 654, 657, 659-60 (2006) (arguing that treaties and international norms support a U.S. right to counsel in civil proceedings).

${ }^{70}$ For example, the ABA advocates both additional funding for indigent defense and civil Gideon. See Richard Klein \& Robert Spangenberg, Am. BAr Ass'N, The In- 
Policy activists find establishing new rights through constitutional adjudication appealing because it circumvents the political process. Courts usually do not consider explicitly whether the government can afford to behave constitutionally. If the Constitution requires lawyers in civil court, the government will have to provide them regardless of cost.

Gideon and its progeny, however, expose two fallacies in this strategy. First, courts weigh issues of cost implicitly even if they do not make them explicit. ${ }^{71}$ Second, even if courts establish new rights, it is up to legislatures to fund them. And if legislatures limit their support, the right will remain underfunded. Darryl Brown has established that state funding for indigent defense is "epiphenomenal." ${ }^{72}$ Using data from all fifty states, Brown showed that funding is determined not by the number of criminal prosecutions in each state, but rather by a complicated blend of political factors largely uncorrelated with the underlying need. ${ }^{73}$ In other words, political forces determine funding, especially because courts find it far easier to lay out broad rights than to force legislatures to fund them. ${ }^{74}$

Thoughtful civil Gideon proponents have thus turned to legislative lobbying. They have achieved some success in California, which in 2009 passed legislation requiring counsel for some civil matters, including child custody and foreclosure proceedings. ${ }^{75}$ Statutory civil Gideon rights may be problematic for other reasons, but at least they leave legislatures free to revise them if they prove unworkable or too expensive. Legislative rationing can be overt and subject to voters' consideration at the polls; by contrast, rationing of judicially created rights occurs through covert subversion and neglect.

DIGENT DEFENSE CRISIS 8 (1993) (reporting on severe under-funding of appointed criminal defense in the United States); infra note 76 and accompanying text.

${ }^{71}$ Argersinger, the case that expanded Gideon to misdemeanor prosecutions, did explicitly discuss the availability of lawyers to staff misdemeanor cases. See 407 U.S. 25, 37 n.7 (1972) (using nationwide statistics to counter the fear noted in Justice Powell's concurrence that there were insufficient attorneys to represent misdemeanor defendants). The majority did not address the cost of these additional lawyers, however. See id.

${ }^{72}$ Brown, supra note 30 , at 908.

${ }^{73} I d$. at $915-20$.

${ }^{74}$ For an excellent overview of the generally unsuccessful attempts to win greater Gideon funding through lawsuits, see Note, supra note 42, at 1736-41.

${ }^{75}$ Act of Oct. 11, 2009, 2009 Cal. Stat. 2498 (codified in scattered sections of CAL. Bus. \& PROF. CODE and CAL. GOV'T CODE); see also Tamara Audi, 'Civil Gideon' Trumpets Legal Discord, WALL ST. J., Oct. 27, 2009, at A3 (describing the funding for the California law). 


\section{TURNER'S TURN TO REALITY}

The Supreme Court's decision to hear Turner spurred renewed optimism among civil Gideon proponents. Many public interest law groups filed amicus briefs supporting the petitioner, arguing that a right to counsel was essential to prevent injustice. ${ }^{76}$ The Court disappointed them, unanimously rejecting the claimed categorical right. The majority advanced three basic reasons for not recognizing a civil right to counsel. First, it recognized that different cases have differing levels of complexity and differing needs for lawyers. Second, it worried about the excessive formality and delay that lawyers often introduce into civil proceedings. Finally, it recognized the availability of less intrusive alternatives, most notably pro se legal assistance. This Part addresses each reason in turn.

\section{A. Gradations of Complexity and Need}

Turner's argument for a civil right to counsel leaned heavily on his interest in avoiding an erroneous deprivation of liberty. The Court acknowledged that his interest in physical liberty was significant and did require due process protection. ${ }^{77}$ But that interest, although significant, was not dispositive.

The Court rightly gave substantial weight to the simplicity of the issue in dispute. Lawyers may be essential to parse complex statutes and technical regulations. But the heart of most child support enforcement actions concerns the basic question of whether the noncustodial parent has the ability to pay. At least when courts follow proper procedures, determining ability to pay is usually a commonsense matter of articulating income, expenses, and assets. Anyone can tell a judge where he works, how much he earns per week, and how much he spends on rent and medical bills.

${ }^{76}$ See, e.g., Brief of Amicus Curiae American Bar Association in Support of Petitioner at 8, Turner v. Rogers, 131 S. Ct. 2507 (2011) (No. 10-10); Brief of Center for Family Policy \& Practice as Amicus Curiae in Support of Petitioner at 2-3, Turner, 131 S. Ct. 2507 (No. 10-10); Brief of Amicus Curiae the Constitution Project in Support of Petitioner at 9-12, Turner, 131 S. Ct. 2507 (No. 10-10); Brief of the Legal Aid Society of the District of Columbia et al. as Amici Curiae in Support of Petitioner at 8, Turner, $131 \mathrm{~S}$. Ct. 2507 (No. 10-10); Brief Amici Curiae of the National Association of Criminal Defense Lawyers et al. in Support of Petitioner at 5, Turner, 131 S. Ct. 2507 (No. 10-10); Brief of Elizabeth G. Patterson et al. as Amici Curiae in Support of Petitioner at 10, Turner, 131 S. Ct. 2507 (No. 10-10).

${ }^{77}$ Turner, 131 S. Ct. at 2518. 
Similarly, every day, unrepresented criminal defendants must prove that they are indigent before they can qualify for court-appointed counsel. ${ }^{78}$ Indigence is a simple factual prerequisite to counsel, not an issue that itself requires counsel. The Court left open whether there might be a right to counsel in the occasional exceptionally complex case, as Turner made no such claim. ${ }^{79}$ But while lawyers might be marginally helpful in routine cases, they are not essential to satisfy due process.

\section{B. Concerns with Formality and Delay}

Nor did the Court subscribe to the faith that lawyers always improve proceedings. Decades earlier, it had noted Judge Friendly's wise caution about lawyers' cost: "Within the limits of professional propriety, causing delay and sowing confusion not only are [the lawyer's] right but may be his duty." ${ }^{80}$ The Court embraced that point in Turner, noting that lawyers can change the nature of proceedings by making them slower and more complex. ${ }^{81}$ One must consider not only the noncustodial parent but also the custodial parent, who is often forced to pursue her claim pro se precisely because she is impoverished by the nonpayment of child support. Providing a lawyer for only one parent would tilt the scales, perhaps making proceedings less fair overall. ${ }^{82}$ In other words, the Court balanced tradeoffs and downsides instead of assuming that more lawyers and more process are always better.

The history of criminal procedure confirms the Court's rational observation that lawyers make proceedings slower and more technical. As John Langbein has argued, the advent of legal representation greatly increased the length and complexity of criminal proceedings. ${ }^{83}$ By

${ }^{78}$ See, e.g., id. at 2518-19.

${ }^{7}$ Id. at 2520.

${ }^{80}$ Walters v. Nat'l Ass'n of Radiation Survivors, 473 U.S. 305, 325 (1985) (quoting Henry J. Friendly, "Some Kind of Hearing," 123 U. PA. L. REV. 1267, 1288 (1975)) (internal quotation marks omitted); see also Gagnon v. Scarpelli, 411 U.S. 778, 787-88 (1973) (explaining that the addition of defense attorneys in revocation proceedings could sacrifice the system's "informality, flexibility, and economy").

${ }^{81}$ Turner, 131 S. Ct. at 2519-20.

${ }^{82}$ See id. at 2519 (cautioning that providing counsel to only one parent could create an "asymmetry of representation" that would undermine the fairness of the proceeding).

${ }^{83}$ See John H. LANGBein, The Origins OF AdVERSARY Criminal Trial 16-17 (2003) (noting that before the advent of the adversarial system, trials took fifteen to thirty minutes); see also John H. Langbein, Understanding the Short History of Plea Bargaining, 13 LAW \& SOC'Y REV. 261, 262-65 (1979) (describing how summary jury trials in the 
the time Gideon was decided, technical rules of evidence, pleading, and procedure had grown too complex for laymen to grasp. Now, "lawyers in criminal courts are necessities, not luxuries," because only they have "skill in the science of law." 84 This requirement may well have been necessary for criminal defendants, given both the Sixth Amendment and the high stakes in criminal cases. But the Court was wise to pause before likewise mandating lawyers in civil cases. That is doubly true, as Section III.C will argue, because of the tension between funding criminal and civil counsel.

Formality and delay may be worth the cost when the stakes are high and the issues are sufficiently complex. Accordingly, the Court left the door open to providing lawyers when both of those factors are present. But only a small fraction of child support cases are complex, and due process rules should be crafted for run-of-the-mill cases, not exceptional ones. ${ }^{85}$ Stronger remedies can be reserved for those exceptions.

\section{Less Intrusive Alternatives}

The final pillar of the Court's reasoning was that alternative measures could satisfy due process. The parties had briefed and argued the case all along as solely a right-to-counsel case, and the merits question presented was limited to that issue. ${ }^{86}$ Other alternatives were never considered nor developed below, so there was no record on the range of alternatives and their efficacy. Justice Thomas's dissent thus criticized the majority for reaching an issue raised for the first time on the merits in an amicus brief. ${ }^{87}$ Nevertheless, the majority gave significant weight to the Solicitor General's suggested alternative procedures. ${ }^{88}$ Those included (1) notifying defendants that ability to pay will be a critical issue; (2) using financial disclosure forms; (3) allowing defendants to respond

eighteenth century processed many more cases than modern courts without the constraints of procedure or presence of counsel).

${ }^{84}$ Gideon v. Wainwright, 372 U.S. 335, 344-45 (1963) (quoting Powell v. Alabama, 287 U.S. 45, 69 (1932)) (internal quotation marks omitted).

${ }^{85}$ See, e.g., Mathews v. Eldridge, 424 U.S. 319, 344 (1976) (emphasizing that rules should be "shaped by . . . the generality of cases, not the rare exceptions").

${ }^{86}$ See Brief for Petitioner at i, 27-51, Turner, 131 S. Ct. 2507 (No. 10-10); Brief of Respondents at 65, Turner, 131 S. Ct. 2507 (No. 10-10) (noting that "petitioner's merits brief explicitly asks for 'a categorical right to counsel, not merely a case-by-case right that depends on the merit or complexity of the case'" (quoting Brief for Petitioner, supra, at 50 n.24)).

${ }^{87}$ Turner, 131 S. Ct. at 2524-25 (Thomas, J., dissenting).

${ }^{88}$ Id. at 2519-20 (majority opinion). 
to follow-up questions about their finances at hearings; and (4) making express findings related to defendants' abilities to pay. ${ }^{89}$

The Court put particular stock in this suggestion because of the federal government's expertise in child support enforcement. ${ }^{90}$ It also noted that while these procedures would be constitutionally sufficient, there might be other alternatives, such as supplying social workers, that could also satisfy due process. ${ }^{91}$ Thus, rather than freezing the law in place, Turner's holding at least acknowledged the possibility of achieving the same goal through different means.

These remedies, the Court noted, not only suffice but also avoid some of the drawbacks of a broad right to counsel. In particular, they avoid the complexity and delay that could make it harder for pro se custodial parents to collect the support they are owed. ${ }^{92}$ In short, the Court's reasoning was at least somewhat sensitive to the policy tradeoffs of mandating appointed counsel across the board.

\section{TWO-AND-A-HALF CHEERS FOR TURNER}

Turner got it right. First, by refusing to constitutionalize a new civil Gideon right, the Court avoided imposing a one-size-fits-all rule on a variety of states and lawsuits. Second, by endorsing much less intrusive alternatives, the Court steered future developments toward more sustainable pro se court reform. And third, by taking into account the complexity of the issue and the interests of pro se custodial parents, the Court accommodated resource constraints and tradeoffs. While the Court could have been more explicit about the need to triage limited resources, its ruling reinforces a sound policy of husbanding scarce funds instead of spreading them too thin.

\section{A. The Wisdom of Not Recognizing a Procrustean Right}

First, neither Turner nor Lassiter held that counsel may never be appointed in particularly complicated or contested civil cases. To the contrary, both cases asked whether the Due Process Clause automatically requires appointed counsel in every termination of parental

${ }^{89} \quad I d$. at 2519.

${ }^{90}$ Cf. id. at 2517 (noting that the "Federal Government has created an elaborate procedural mechanism designed to help both the government and custodial parents to secure the payments to which they are entitled").

${ }^{91}$ Id. at 2519.

${ }^{92} I d$. at 2519-20. 
rights or civil contempt/child support case..$^{93}$ An indigent litigant can still request appointed counsel, and the judge must weigh, case by case, whether fundamental fairness requires appointing a lawyer. ${ }^{94}$ Thus, the question is not whether allowing some defendants to go unrepresented in civil contempt cases is sometimes fundamentally unfair, but whether it is always or very often unfair. For child support proceedings, the answer is no: the opposing party is often unrepresented and the issue is simple, so lawyers are not essential across the board.

Second, the Court finally acknowledged that lawyers can sometimes make proceedings less fair. The Court's Sixth Amendment cases have regularly praised counsel as indispensable for procedural fairness. In Powell, the Court waxed eloquent about how "[t]he right to be heard" would be hollow without "the guiding hand of counsel" "skill[ed] in the science of law." "95 Gideon likewise recognized the "obvious truth" that lawyers uphold the "noble ideal" of "fair trials before impartial tribunals." 96 And, in Miranda, where the Court sought to protect the right to remain silent, it mandated warning suspects that they have the right to an attorney. ${ }^{97}$ In so doing, the Court praised counsel's "vital role" in protecting the accused while promoting the administration of justice. ${ }^{98}$

The Court has long equated more lawyers with more justice-but that faith is finally waning. In other recent cases, the Court has rejected attorneys' claims that the lawyer-client relationship or the duty of zeal-

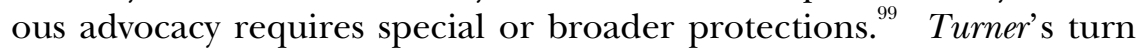

${ }^{93} I d$. at 2520; see also Lassiter v. Dep't of Soc. Servs., 452 U.S. 18, 31-32 (1981) (" $[\mathrm{N}]$ either can we say the Constitution requires the appointment of counsel in every parental termination proceeding.”).

${ }^{94}$ Lassiter, 452 U.S. at 32-34.

${ }^{95}$ Powell v. Alabama, 287 U.S. 45, 68-69 (1932).

${ }^{96}$ Gideon v. Wainwright, 372 U.S. 335, 344 (1963). The Court followed this language with a long quotation of "the moving words of Mr. Justice Sutherland in Powell $v$. Alabama." Id.

${ }^{97}$ Miranda v. Arizona, 384 U.S. 436, 471 (1966).

${ }^{9} I d$. at $480-81$.

${ }^{99}$ For example, the Court overturned lower court decisions offering lawyers special protections from facially neutral statutes in a pair of 2010 cases. See Jerman v. Carlisle, McNellie, Rini, Kramer \& Ulrich LPA, 130 S. Ct. 1605, 1622 (2010) (holding that a debt-collecting lawyer's duty to comply with the Fair Debt Collection Practices Act overrides the ethical duty to advance his client's interests); Milavetz, Gallop \& Milavetz P.A. v. United States, 130 S. Ct. 1324, 1331-33 (2010) (rejecting the argument that the federal prohibition on debt-relief agencies advising clients to incur more debt before filing for bankruptcy does not apply to law firms). Similarly, in Montejo v. Louisiana, the Court held that police officers could contact criminal defendants after the appointment of counsel. 129 S. Ct. 2079, 2087 (2009). In so holding, the Court explicitly rejected arguments based upon the sanctity of the lawyer-client relationship and the existence of an ABA Model Rule of Professional Conduct barring contact with represented parties. 
away from blind faith in lawyers as indispensable for fair trials is a significant part of this landmark development.

\section{B. More Sustainable Pro Se Court Reform}

All over the country, state and local courts are deluged by pro se litigants. ${ }^{100}$ The crush of pro se litigation has been one of civil Gideon proponents' main arguments. Yet the Court and academics have largely ignored this phenomenon. Outside of the civil Gideon debate, however, lower courts have begun a quiet procedural revolution. All over the country, judges, court administrators, legal aid lawyers, and advocates for the poor have been working together on pro se court reform. These reforms aim to make court processes simpler, fairer, and more user-friendly.

Examples of organized pro se court reform abound. In 2005, the American Judicature Society (AJS) published a guide for judges interested in making their courts more pro se friendly. ${ }^{101}$ The SelfRepresented Litigation Network has also published a set of core materials gathering national best practices. ${ }^{102}$ The National Center for State Courts has published The Self-Help Friendly Court: Designed from the Ground Up to Work for People Without Lawyers. ${ }^{103}$ And various research

Id. As the Court put it, "[T] he Constitution does not codify the ABA's Model Rules, and does not make investigating police officers lawyers." Id.

${ }^{100}$ See Gillian Hadfield, A Case for Legal Aid at Wal-Mart, WASH. Post, Mar. 12, 2010, at A17.

${ }^{101}$ See Cynthia Gray, Am. JUdicature SoC'y \& State Justice InST., REACHing OUT OR OVERREACHING: JUdicial ETHICS AND SELF-REPRESENTED LiTigANTS (2005). The report presents a list of commonsense steps that judges may take to help pro se litigants, and contains a section on "Proposed Best Practices." Id. at 51-57. These include making procedural accommodations, being courteous, avoiding legal jargon and procedural snafus, explaining the process, avoiding over-familiarity with lawyers in the courtroom, and training court staff to provide patient and helpful service to selfrepresented litigants. Id.

${ }^{102}$ See The Self-Represented Litig. Network, Core Materials ON SelfREPRESENTED LITIGATION INNOVATION (2006) (listing articles and websites that provide information and research on pro se litigation).

${ }^{103}$ Richard ZORZA, NAT'L CTR. FOR STATE COURTS, THE SELF-HELP FRIENDLY COURT: DESIGNED FROM THE GROUND UP TO WORK FOR PEOPLE WITHOUT LAWYERS (2002), available at http://www.ncsconline.org/WC/Publications/Res_ProSe_SelfHelpCtPub.pdf. The Preface, written by the Chief Justice of the California Supreme Court, chronicles California's recent efforts to improve pro se court access, including a nine-hundredpage self-help guide on its website for pro se litigants that is visited over 100,000 times per month. Id. at 7-8. AJS even has an online forum dedicated to pro se issues. Pro Se Forum, AM. JUDICATURE SOC'Y, http:/ /www.ajs.org/prose/home.asp (last visited Jan. 15, 2012); see also Richard Zorza, Self-Represented Litigants and the Access to Justice Revolution in 
projects have observed and proposed a number of innovative court processes to improve access for pro se litigants. ${ }^{104}$

The national adoption of court-appointed special advocate (CASA) programs for custody matters serves as a model of innovation in promoting access to justice. ${ }^{105}$ These nonlawyer advocates assist courts and pro se litigants for a fraction of the cost of retaining an attorney. Turner endorsed these programs by mentioning the possibility of having social workers assist in child support disputes. ${ }^{106}$

Forward-thinking lower courts have established innovative programs as well. For example, the Eastern District of New York has created a special magistrate court for pro se matters, and San Antonio has established a pro se assistance program in its civil courts. ${ }^{107}$

The reports, studies, and programs listed above describe only government-supported pro se efforts. But there are also many for-profit pro se assistance websites like legalzoom.com and rocketlawyer.com. If one considers both private and public options, opportunities for innovative, inexpensive, and effective pro se representation are improving exponentially.

Properly understood, Turner recognizes and protects pro se litigants. It offers courts and poverty advocates a once-in-a-generation opportunity: the chance to move beyond 1963 solutions to 2012 court problems. Not every court dispute requires a lawyer's involvement, and neither litigants nor society can afford lawyers for each dispute.

the State Courts: Cross-Pollinating Perspectives Toward a Dialogue for Innovation in the Courts and the Administrative Law System, 29 J. NAT'L ASSOC. ADMIN. L. JUdICIARY 63, 68-74 (2009) (describing various courts' efforts to expand access to justice including self-help centers, simplifying forms, improving technological availability, staff training, and others).

${ }^{104}$ See, e.g., Ronald W. Staudt \& Paula L. Hannaford, Access to Justice for the SelfRepresented Litigant: An Interdisciplinary Investigation by Designers and Lawyers, 52 SYRACUSE L. REV. 1017, 1029-41 (2002) (listing primarily technical solutions proposed by design and law students after observing problems in self-represented litigation).

${ }^{105}$ See, e.g., About Us, CASA FOR CHILDREN, http://www.casaforchildren.org/site/ c.mtJSJ7MPIsE/b.5301303/k.6FB1/About_Us_CASA_for_Children.htm (last visited Jan. 15, 2012) (describing a program of citizen advocates who help place abused children in new homes).

${ }^{106}$ Turner v. Rogers, 131 S. Ct. 2507, 2519 (2011).

${ }^{107}$ See Lois Bloom \& Helen Hershkoff, Federal Courts, Magistrate Judges, and the Pro Se Plaintiff, 16 Notre Dame J.L. ETHics \& Pub. Pol'y 475, 493-97 (2002) (detailing the New York program); see also Anita Davis, A Pro Se Program That Is Also "Pro" Judges, Lawyers, and the Public, 63 TEx. B.J. 896, 896 (2000) (describing how Bexar County civil courts employ a staff attorney to assist courts and pro se litigants in preparing dockets, coordinating mediation and litigation, and answering general questions). 
Rather than looking backward to Gideon, Turner invites forwardlooking, flexible pro se alternatives.

The danger is that Turner's minimal suggestions will ossify. Turner itself suggests rather limited safeguards: notice, a form, an opportunity to respond at a hearing, and a clear finding. ${ }^{108}$ But the Court quite explicitly stated that these are not "the only possible alternatives" and that other forms of pro se assistance (like a neutral social worker) may also be helpful. ${ }^{109}$ Nevertheless, the Supreme Court's suggestions in practice often become not only a constitutional floor, but also a ceiling. ${ }^{110}$ Instead of falling into this pitfall and abandoning experimentation, lower courts should use Turner as a spur to further innovation.

Judges and court clerks cannot address pro se-heavy dockets by trying to recreate the traditional adversarial system without lawyers. Instead, all court personnel must adopt a more managerial posture. Courts in civil-law nations may be apt models for study and imitation. ${ }^{111}$ Courts should also carefully examine the sufficiency of existing pro se practices. For example, sometimes hearings do not even include explicit findings of fact. ${ }^{112}$

${ }^{108}$ Turner, $131 \mathrm{~S}$. Ct. at 2519. Ossification would be especially unfortunate because the Court, reaching the issue sua sponte, did not have the benefit of research or briefing on the various procedures with which states are experimenting to facilitate pro se access to civil justice.

109 Id.

${ }^{110}$ For example, Miranda warnings were supposed to be only one way of preventing compelled self-incrimination, but the Court's imprimatur has made them universal. See Miranda v. Arizona, 384 U.S. 436, 444 (1966) (requiring the now-famous Miranda warnings "unless other fully effective means are devised to inform accused persons of their right of silence and to assure a continuous opportunity to exercise it"); Dickerson v. United States, 530 U.S. 428, 443-44 (2000) (concluding that "Miranda announced a constitutional rule that Congress may not supersede legislatively" partially because " $M i$ randa has become embedded in routine police practice to the point where the warnings have become part of our national culture").

${ }^{111}$ See generally JOHN HENRY MERRYMAN \& ROgElio PEREZ-PODOMO, The CiVIL

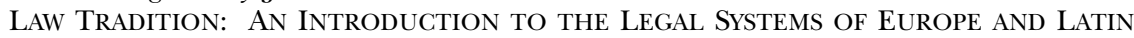
AMERICA 34-38 (3d ed. 2007) (contrasting the role of the judge in common law and civil law courts).

${ }^{112}$ In Turner, for example, while the child support court found Turner in contempt, the judge did not indicate on the preprinted contempt-of-court form whether "he was or was not gainfully employed, nor whether he had the ability to make these support payments when due." 131 S. Ct. at 2514. Findings of fact are important to permit meaningful appellate review of the lower court's holding and reasoning. In Turner, civil contempt required a showing of a willful refusal to pay, but there was no explicit finding on that issue. Id. at 2513. 
Though the Court has finally recognized the need for alternative procedures, legislatures, academics, court administrators, public interest groups, and others must continue to innovate to promote pro se access to justice.

\section{The Implicit Role of Resource Constraints}

We live in a world of scarcity. In the past, the Supreme Court has repeatedly acknowledged funding constraints as a reason not to expand the right to counsel: lawyers and complex procedures cost time and money, meaning that the needy have less overall funding. ${ }^{113}$ As Judge Friendly put it, "[A]t some point the benefit to individuals from an additional safeguard is substantially outweighed by the cost of providing such protection, and ... the expense of protecting those likely to be found undeserving will probably come out of the pockets of the deserving." 114

Based on this scarcity, Congress has specifically declined to fund appointed counsel in child support-related civil contempt cases such as Turner. ${ }^{115}$ Likewise, some states have reserved appointed counsel for criminal and unusually complex civil cases. State courts usually retain discretion to appoint counsel in civil actions that are too complex for pro se litigants to defend themselves. ${ }^{116}$ The Supreme Court has avoided treading on these legislative and judicial judgments.

Civil Gideon advocates tend to focus on one type of case in isolation. But in a world of tight budgets, criminal and civil defense compete for funding. Tradeoffs are inevitable, and the need for appointed

${ }^{113}$ See, e.g., Walters v. Nat'l Ass'n of Radiation Survivors, 473 U.S. 305, 326 (1985) (giving "great weight" to the government's interest in avoiding increased administrative costs for veterans' hearings); Gagnon v. Scarpelli, 411 U.S. 778, 788 (1973) (citing the "financial cost to the State" of requiring appointed counsel).

${ }^{114}$ Friendly, supra note 80, at 1276, quoted with approval in Walters, 473 U.S. at 321 n.9.

${ }^{115}$ See S. REP. No. 98-387, at 23 (1984) (explaining that Congress does not intend to provide federal matching for expenditures in child support-enforcement programs for providing defense counsel to indigent parents); see also 45 C.F.R. $\$ 304.23$ (i)-(j) (2010) (barring expenditure of federal funds for indigent defense counsel or costs relating to jailing parents in child support enforcement); Child Support Enforcement Program; Prohibition of Federal Funding of Costs of Incarceration and Counsel for Indigent Absent Parents, 52 Fed. Reg. 32,130, 32,130 (Aug. 26, 1987) (codified at 45 C.F.R. pt. 304) (including certain expenses-such as providing defense counsel to indigent parents-in list of expenditures for which federal funds are not available).

${ }^{116}$ See, e.g., S.C. APP. CT. R. 608(g) (1) (granting state judges discretion in appointing counsel but cautioning that " $[\mathrm{t}]$ he unnecessary appointment of lawyers ... places an undue burden on the lawyers of this State"); Ex parte Foster, 565 S.E.2d 290, 293 (S.C. 2002) (remanding for a determination of whether the action was "so complex" that failing to appoint a lawyer would "unfairly hamper [respondent's] ability to defend his case"). 
counsel is far greater in felony cases, especially capital cases. Felony cases, unlike civil cases, carry a Sixth Amendment right to trial by jury and so entail jury instructions, arguments, and related complexities. Felony cases also involve elaborate criminal procedures, ranging from formal rules of evidence to constitutional disclosure requirements. Felony cases pit individual defendants against experienced, professional police and prosecutors wielding the power of the state. ${ }^{117}$ Felony convictions often carry collateral consequences, including criminal records and disqualification from jobs, and they also impose criminal stigma. And, of course, felony convictions can result in long prison sentences or even the death penalty.

Some exceptional civil cases may merit counsel, either because they are particularly complex or because they are otherwise especially important or meritorious. But these determinations demand case-bycase judgments, not blanket constitutional rules. Legal aid societies and trial courts already triage their caseloads, selecting a fraction of civil cases as most deserving and most in need of limited resources. Constitutional rules would fetter this contextual exercise of discretion with mandatory, rigid requirements.

Moreover, there is little evidence that lawyers make much of a difference in simple cases. Most studies of lawyers in civil litigation have been observational case studies flawed by nonrandom assignment of lawyers to possibly more meritorious cases. ${ }^{118}$ Two Harvard researchers reviewed the existing literature and found "astonishingly little credible, quantitative information about the effect of representation." The only two studies that were methodologically sound reached conflicting results; in the one study that found that lawyers affected outcomes, those effects disappeared in informal proceedings. ${ }^{120}$ The Harvard researchers have conducted their own randomized, con-

117 Cf. Turner v. Rogers, 131 S. Ct. 2507, 2520 (2011) ("[T]he average defendant does not have the professional legal skill to protect himself when brought before a tribunal with power to take his life or liberty, wherein the prosecution is presented by experienced and learned counsel." (quoting Johnson v. Zerbst, 304 U.S. 458, 462-63 (1938) (emphasis added by the Court in Turner)).

${ }^{118}$ See D. James Greiner \& Cassandra Wolos Pattanayak, Randomized Evaluation in Legal Assistance: What Difference Does Representation (Offer and Actual Use) Make?, 121 YALE L.J. (forthcoming 2012) (manuscript at 56), available at http://ssrn.com/ abstract=1708664 (describing previous studies as "unworthy of credence" and observing that "the only way to produce credible quantitative results . . . is with randomized trials").

${ }^{119} I d$. at 69.

${ }^{120}$ Id. at $68-69$. 
trolled study of administrative unemployment hearings. ${ }^{121}$ They found no significant difference in success rates between defendants who were offered free legal representation and those who were not. ${ }^{122}$ In fact, the only major difference was that introducing lawyers delayed case resolution. $^{123}$ Based on these findings, there seems to be little benefit to providing lawyers across the board, especially in simple cases.

Another empirical study has reached the same conclusion about routinely appointing counsel in misdemeanor cases. Erica Hashimoto found that federal pro se misdemeanor defendants average lower rates of conviction and lower sentences in all categories of cases except for driving under the influence. ${ }^{124}$ Hashimoto's research indicates that lawyers appear to add less value in simple misdemeanor cases than in more complex and serious cases. ${ }^{125}$ Because procedures are simpler and the stakes are lower, lawyers simply have much less to do. A sensible triage policy would take that simplicity into account.

Finally, funding realities mean that states cannot and do not provide civil counsel across the board even where required by law. In 2006, the Supreme Court of New Jersey ordered the State to appoint counsel before confining nonsupporting parents for civil contempt. ${ }^{126}$ In the wake of that ruling, however, New Jersey was not able to fund such counsel. ${ }^{127}$ Thus, until Turner, child support officials had to release nonsupporting parents who qualified for appointed counsel, instead of enforcing child support through civil contempt. ${ }^{128}$

Likewise, Pennsylvania courts presume that poor defendants are entitled to appointed counsel whenever they face loss of physical liberty. ${ }^{129}$ Despite this presumption, Pennsylvania counties have repeatedly failed

121 Id. at 12 .

${ }^{122} I d$. at 26 .

${ }^{123}$ Id. at $44-45$.

${ }^{124}$ Hashimoto, supra note 44, at 490-93 \& tbls.2-6.

${ }^{125} I d$. at 496.

${ }^{126}$ See Pasqua v. Council, 892 A.2d 663, 674 (N.J. 2006) (grounding this right in the Fourteenth Amendment's Due Process Clause), abrogated by Turner v. Rogers, 131 S. Ct. 2507 (2011).

${ }^{127}$ See Brief of Senators DeMint et al. as Amici Curiae in Support of Respondents at app. 8a, Turner, 131 S. Ct. 2507 (No. 10-10) (reporting data collected by the Office of Child Support Enforcement at the U.S. Department of Health and Human Services from states' child support-enforcement authorities, including New Jersey's).

${ }^{128}$ See id. (noting that, because it has no funding, New Jersey had to release all nonsupporting parents found to be indigent if they are held in contempt).

${ }^{129}$ See Commonwealth v. \$9,847.00 U.S. Currency, 704 A.2d 612, 615-17 (Pa. 1997) (acknowledging "a presumption" that "an indigent litigant has a right to appointed counsel ... when, if he loses, he may be deprived of his physical liberty" (quoting Lassiter v. Dep't of Soc. Servs., 452 U.S. 18, 26-27 (1981)) (internal quotation marks omitted)). 
to appoint counsel for indigent parents facing civil contempt. ${ }^{130}$ The civil Gideon right collided with funding realities.

Even where lawyers are appointed in child support cases, they are often too overburdened to provide much help. They have neither the time nor resources to investigate the circumstances of the case or provide meaningful counsel to their clients. Often, they can do little more than parrot to the judge what their clients have told them. "In many of the [child support] courtrooms we watched, these attorneys would call out their client's name as the court room filled with cases, meeting the client for the first time just prior to the hearing." ${ }^{131}$ When lawyers juggle many cases and learn little about each one, they can add little value for their clients or for the justice system overall. ${ }^{132}$

Yet the public interest bar has been slow to recognize these realities. The American Bar Association, the National Association of Criminal Defense Lawyers, and the Constitution Project have all protested the limited funding of criminal defense counsel. ${ }^{133}$ The Center for Family Policy and Practice has noted that lawyer-for-a-day programs provide very few benefits. ${ }^{134}$ Yet all of these organizations also filed amicus briefs in Turner in support of a broad civil Gideon right. ${ }^{135}$

Setting aside the American Bar Association's self-interest in securing more funding for its members, the problem represents a refusal to accept reality. The organizations hope for a new judicial ruling guaranteeing the right to counsel in civil cases, but at the same time decry how underfunding subverts existing rights to counsel in practice. New rulings recognizing expanded rights will not increase the amount of available funding; instead, they will compete with other rights to coun-

${ }^{130}$ See, e.g., Application for Extraordinary Relief Under Pa. R.A.P. § 3309 and King's Bench Powers at 10, Cepeda v. Court of Common Pleas, No. 128 MM 2009, slip op. (Pa. June 24, 2010) (claiming that eight indigent petitioners were imprisoned for contempt after allegedly failing to pay child support, without being represented by counsel or informed they had a right to counsel); Brief Amici Curiae of the National Ass'n of Criminal Defense Lawyers et al., supra note 76, at 28-29 (maintaining that "indigent parents facing contempt charges in Pennsylvania are not being provided with counsel").

131 Rebecca May \& Marguerite Roulet, Ctr. For Family Policy \& Practice, A LOOK AT ARRESTS OF LOW-INCOME FATHERS FOR CHILD SUPPORT NONPAYMENT: ENFOrcement, COURT AND Program Practices 45 (2005), available at http://www.cprmn.org/Documents/noncompliance.pdf.

${ }^{132}$ See id. (noting that adding lawyers with high case turnover will do little to "persuade a judge to be lenient, even when the facts of the case might merit leniency").

${ }^{133}$ See supra notes 39-41 and accompanying text.

134 See supra notes 131-32 and accompanying text.

${ }^{135}$ See supra note 76. 
sel, spreading funding ever thinner. The result may be a Pyrrhic victory: lawyer-for-a-day programs that provide counsel in name only.

\section{CONCLUSION}

Turner arrives at a particularly interesting time for the judiciary and the legal profession. While technology has transformed most other areas of life, court-based dispute resolution has remained remarkably impervious to change. Courts across the country must adapt an adversary system designed to be navigated by expert counsel to the realities of mass pro se representation.

If pro se reform is to go beyond the bare minimum, stakeholders must work together. Judges, court administrators, and clerks must accelerate their efforts to accommodate the pro se flood. Judges need to recognize that, in many pro se cases, a more aggressive and inquisitorial approach is appropriate. Court clerks must cease refusing to answer questions or assist pro se litigants for fear of the unauthorized practice of law.

Bar associations and judges will likewise need to rethink strict enforcement of unauthorized-practice-of-law rules. Throughout the economy, routine and mechanical tasks are being outsourced or handled by computers. Lawyers can try in vain to stem that tide by prosecuting unauthorized practice of law, or they can abandon cookiecutter cases and focus on those that need individualized legal judgment. Where the law is simple and disputes are factual, paralegals, investigators, and social workers can help to investigate facts, marshal evidence, and prepare clients to tell their own stories.

The real danger to the legal profession has always been that pro se court reform will spread upwards from the poor to the middle class and beyond. Certainly, paid divorce lawyers have little incentive to support straightforward, cheap, and fast pro se divorces for the poor. What is bad for lawyers, however, may be good for citizens and the economy as a whole by reducing the deadweight burden of legal fees.

Technology may make these disputes moot sooner rather than later. In the meantime, the Court in Turner was right to recognize that more lawyers do not always equal more justice and that fair pro se procedures are better for everyone. Other actors must now translate pro se court reform from Turner's sketch into a viable pro se system. 